IZA DP No. 8823

Disruptive School Peers and Student Outcomes

Jannie H. G. Kristoffersen

Morten Visby Krægpøth

Helena Skyt Nielsen

Marianne Simonsen

January 2015 


\title{
Disruptive School Peers and Student Outcomes
}

\author{
Jannie H. G. Kristoffersen \\ Copenhagen Business School
}

Morten Visby Krægpøth

Aarhus University

Helena Skyt Nielsen

Aarhus University and IZA

Marianne Simonsen

Aarhus University and IZA

\section{Discussion Paper No. 8823 \\ January 2015}

\author{
IZA \\ P.O. Box 7240 \\ 53072 Bonn \\ Germany \\ Phone: +49-228-3894-0 \\ Fax: +49-228-3894-180 \\ E-mail: iza@iza.org
}

\begin{abstract}
Any opinions expressed here are those of the author(s) and not those of IZA. Research published in this series may include views on policy, but the institute itself takes no institutional policy positions. The IZA research network is committed to the IZA Guiding Principles of Research Integrity.

The Institute for the Study of Labor (IZA) in Bonn is a local and virtual international research center and a place of communication between science, politics and business. IZA is an independent nonprofit organization supported by Deutsche Post Foundation. The center is associated with the University of Bonn and offers a stimulating research environment through its international network, workshops and conferences, data service, project support, research visits and doctoral program. IZA engages in (i) original and internationally competitive research in all fields of labor economics, (ii) development of policy concepts, and (iii) dissemination of research results and concepts to the interested public.
\end{abstract}

IZA Discussion Papers often represent preliminary work and are circulated to encourage discussion. Citation of such a paper should account for its provisional character. A revised version may be available directly from the author. 
IZA Discussion Paper No. 8823

January 2015

\section{ABSTRACT}

\section{Disruptive School Peers and Student Outcomes}

This paper estimates how peers' achievement gains are affected by the presence of potentially disruptive and emotionally sensitive children in the school-cohort. We exploit that some children move between schools and thus generate variation in peer composition in the receiving school-cohort. We identify three groups of potentially disruptive and emotionally sensitive children from detailed Danish register data: children with divorced parents, children with parents convicted of crime, and children with a psychiatric diagnosis. We find that adding potentially disruptive children lowers the academic achievement of peers by about 1.7-2.3 percent of a standard deviation.

JEL Classification: $\quad 121, \mathrm{~J} 12$

Keywords: student mobility, special educational needs, education, value added model

Corresponding author:

Helena Skyt Nielsen

Department of Economics and Business

Aarhus University

Fuglesangs Allé 4

DK-8210 Aarhus V

Denmark

E-mail: hnielsen@econ.au.dk

\footnotetext{
*We appreciate comments from two anonymous referees, Steffen Andersen, Anne B. Nandrup, Louise V. Beuchert, and seminar participants at Aarhus University. We would also like to thank participants at the 2014 IWAEE and the 2014 EALE conference. Financial support from the Danish Council for Strategic Research (CSER, 09-070295) and the Danish Council for Independent Research (Sapere Aude Starting Grant, 10-079597) is gratefully acknowledged. The usual disclaimers apply.
} 


\section{Introduction}

During the last decade, a consensus has developed that all learners should be educated within the mainstream sector. Therefore, countries across the world strive to establish inclusive settings within the compulsory education system (see the review by European Agency for Development in Special Needs Education, 2013). It is imperative to foresee and understand the extent of potential consequences of this policy trend. Recent evidence suggests that inclusion of disadvantaged children in mainstream classrooms exert negative effects on the other learners (e.g. Figlio, 2007; Carrell and Hoekstra, 2010; Cho, 2012; Kristoffersen, 2013; and Diette and Uwaifo Oyelere, 2014). One paper (Hanushek, Kain and Rivkin, 2002) finds small positive but insignificant effects of sharing a classroom with a disabled student. Our paper adds to this sparse literature.

This study is concerned with the impact of the presence of potentially disruptive and emotionally sensitive children in one's school-cohort. We approximate disruptiveness by early student characteristics and quality of the home environment prior to school enrolment. Hence we do not rely on measures of current behavior that may be difficult to handle for simultaneity reasons. Our estimation strategy exploits children who move into the school-cohort and thus generate variation in peer composition. For this exercise, we rely on population-wide Danish register-based data that provide us with a panel of pupils and schools. Importantly these data allow us to control for prior student performance and school fixed effects.

Our main contributions are the following: Firstly, compared to the existing literature, we consider a broader group of disruptive and emotionally unstable children. Specifically, we look at children whose parents have divorced, whose parents have a criminal history, and who themselves have an early psychiatric diagnosis. This is appealing because disruptiveness may easily extend beyond children exposed to extreme and violent home environments as analyzed by Carrell and Hoekstra (2010). Fewer than 5\% are exposed to domestic violence in their sample and effects of less problematic exposures may be just as interesting. Secondly, the availability of unique population wide individual level panel data allows us to improve upon the estimation strategy compared to much previous work. Like for instance Fletcher (2009) for children with emotional problems and Cho (2012) and Diette and Uwaifo Oyelere (2014) for English Language Learners (ELL), we employ a value added model which implies that our disruptiveness measure is only required to be exogenous with regards to changes in test scores, not with regards to levels of test scores. However, our strategy does not rely on variation in disruptive classmates within school-grade or within 
individual. Rather it explicitly exploits movements of supposedly disruptive or emotionally sensitive children across schools.

We first document that children with divorced or criminal parents or own psychiatric diagnoses have on average worse behavior than their classroom peers. Then we present evidence that receiving a potentially disruptive child can have negative consequences for peers in the receiving school-cohort, in the sense that it lowers their immediate academic achievement in reading by about 1.7-2.3 percent of a standard deviation. The strongest and most robust effects seem to come from children with a psychiatric diagnosis or whose parents have a criminal history, while children with divorced parents exert no significant effect on test scores of peers on average. However, when we allow disruptive boys and girls to have different effects, we find that a boy with divorced parents does seem to disrupt peers to an extent that is reflected in their test scores.

Our paper contributes not only to the literature on the effects of disadvantaged children in mainstream classrooms; we also speak to the literatures concerned with consequences of peer performance and characteristics more generally (see Epple and Romano (2011) and Sacerdote (2011) for overviews). Our study is, for example, related to two recent contributions by Lavy, Silva, and Weinhardt (2012) and Lavy, Paserman and Schlosser (2012) that both document that a higher proportion of low-achieving peers is detrimental for pupil achievement. ${ }^{1}$ It is also related to Black, Devereux, and Salvanes (2013) who is concerned with peers' background characteristics. They find evidence that the proportion of girls improves female (but not male) outcomes and that higher earnings among peers' fathers improve male outcomes. Lavy and Schlosser (2011) find positive effects of having a large fraction of girls in the classroom for both boys and girls. Other examples of this type of work are studies of the impact of school desegregation programs, where some studies find scattered and moderate effects of balancing the racial composition (Angrist and Lang, 2004; Hoxby and Weingarth, 2006), while others find substantial effects (Billings, Deming and Rockoff, 2014).

The paper is structured as follows: Section 2 gives a brief overview of the institutional setting, Section 3 presents our data, and Section 4 discusses our identification strategy, Section 5 describes our measures of disruptive children, Section 6 reports results, and Section 7 concludes.

\footnotetext{
${ }^{1}$ Imberman, Kugler, Sacerdote (2012) and Hanushek et al. (2003) document significant effects of average peer quality.
} 


\section{Institutional setting}

\subsection{Elementary Schools in Denmark}

For the period relevant to our study education is compulsory from the calendar year the child turns 7 until the child has completed $9^{\text {th }}$ grade. ${ }^{2}$ Before the $1^{\text {st }}$ grade there is an optional preschool year with a take-up of $83 \%$ in 2005 (UNI-C, 2012). After the completion of $9^{\text {th }}$ grade the pupil can either enroll in high school or in vocational school. The preschool class, $1^{\text {st }}$ to $9^{\text {th }}$ grade as well as postcompulsory schooling are free of charge, as long as they are taken on public schools; private schools and boarding schools charge tuition fees.

In the preschool class, pupils are taught by a form teacher, but from $1^{\text {st }}$ grade to $9^{\text {th }}$ grade, pupils are taught by subject specific teachers. The same subject specific teacher follows the pupils through several grades. There are no general regulations as to the organization of teachers across grades. However, many schools are informally divided into age groups preschool- $3^{\text {rd }}$ grade, $4^{\text {th }}-6^{\text {th }}$ grade, and $7^{\text {th }}-9^{\text {th }}$ grade, and each teacher will typically specialize in their subject teaching within one age group. Classes consist in general of no more than 28 pupils. Each class has one or two main responsible teachers (typically the teachers in Danish and/or math), who cover the main part of their lectures during a number of school years. Most schools offer all grades up until grade 9 but there are some small schools that only offer a subset of these, often up until grade 6 or 7 , the pupils then finish compulsory schooling at another school.

\subsection{National Tests}

Danish school children have not been systematically evaluated in the lower grades until 2010 . Before 2010 the children were only systematically graded from $8^{\text {th }}$ grade and they experienced their first exam at the end of $9^{\text {th }}$ grade (at around age 16). After some years of poor performance in OECD's PISA-test (2000 and 2003), the parliament decided to introduce systematic nationwide testing throughout compulsory school.

The National Tests are IT-based, self-scoring and adaptive tests. ${ }^{3}$ The test score is based on a precise measure of student ability rather than a count of the number of correct answers. Instead of giving all pupils the same questions and summing up the number of correct answers, the software

\footnotetext{
${ }^{2}$ In 2009 the preschool year became compulsory, but the youngest cohort in this study started preschool in 2008.

${ }^{3}$ For details on the national tests, see Beuchert and Nandrup (2014).
} 
calculates an ability measure after each question and then finds a question with a difficulty level that matches the contemporary measure of the pupil's ability level. After each question the software re-estimates a new ability level and the difficulty level of the next question is based on a RASCHalgorithm that ensures that the student is given questions that he or she has a $50 \%$ probability of answering correctly. Thus the final ability estimate is not a function of the number of correct answers but instead a function of the difficulty level of the questions and the ability of the student. The final ability measures are distributed from -7 to 7 on a logit scale.

The test is designed to simultaneously estimate the pupil's ability within three profile areas of each subject, and the algorithm will alternate questions testing each of these three profile areas. In this paper we focus on the tests in reading in $2^{\text {nd }}, 4^{\text {th }}, 6^{\text {th }}$, and $8^{\text {th }}$ grade and use the tests in math in $3^{\text {rd }}$ and $6^{\text {th }}$ grade as a robustness test. The three profile areas in reading are 1) Language Comprehension, 2) Decoding, and 3) Reading Comprehension and in math they are 1) Numbers and Algebra, 2) Geometry, and 3) Mathematics in Use.

The National Tests are primarily thought to have a pedagogical purpose rather than an accountability purpose. Thus, the main purpose of the tests is to give feedback to teachers, pupils and parents, about the ability level of the individual child. In principle, the teacher can assist weak children and/or provide the child with aids or breaks during the test. Information on assistance or aid given to the pupil is unfortunately not available for researchers but obviously it is known by the teacher and child. The tests are in principle compulsory for all students enrolled in public schools, but headmasters may exempt students from the test. Our identification strategy accounts for these issues, and we will elaborate on this in the section about the empirical strategy.

\section{Data}

We exploit administrative data for the entire Danish population maintained by Statistics Denmark. These include key individual level test score data from the National Tests (spring 2010-2013) in addition to school identifiers and socio-economic background information about pupils and their parents. Important for our empirical strategy, we are able to identify children who move between schools. We identify three groups of potentially disruptive children through their background characteristics: children with parents who have divorced before the child turned 6 , children with parents convicted of a crime before the child turns 6 , and children diagnosed with a psychiatric 
diagnosis before he or she turned $9 .{ }^{4}$ All other child and parent information is measured at age 5, which is the year before they start school, in order to ensure that school experiences do not influence the background characteristics. We define parents as divorced if they do not live at the same address on January 1 in the year the child turns $5 .{ }^{5}$ We define parents as criminal if either the father or the mother has been convicted of a non-traffic crime or has been sentenced to prison because of sufficiently severe traffic-related crime before the child turns 6 . We define children with a psychiatric diagnosis based on registered psychiatric diagnoses at general hospitals before age 9 .

From the full population, we select children enrolled in public schools in mainstream classrooms who took the National Test in reading or math in the relevant years; ${ }^{6}$ see Table A1. We restrict our sample to only contain cohorts from schools where at least some of the students continued on the same school until the end year. In that way we exclude cohorts from schools that close and from small schools that did not offer the relevant grades. We also remove the very small school-cohorts (less than 10 pupils) along with the very large ones (more than 200 pupils). When we run our regressions, we exclude potentially disruptive students who move and thus create our identifying variation, such that their test scores are not included in the analysis, this reduces our sample sizes even further. We use variation at the school-cohort level rather than the classroom level. We believe that it is more likely that the mobility of students is exogenous at the school-cohort level than at the classroom level, because the school principal might sort new students across classrooms and teachers, based on different unobservable criteria.

Table A2 defines our background variables and Table A3 shows means of outcome variables and background characteristics of the children in our main sample covering children with test scores in reading. Outcome variables are z-scores from the National Tests. ${ }^{7}$ The receiving school-cohorts score lower on test scores after the new children have entered the school-cohort, than non-receiving school-cohorts do. Note that they also scored lower in the base year. Furthermore, these school-

\footnotetext{
${ }^{4}$ We choose a higher age limit for psychiatric diagnoses because such diagnoses are rare before the age of 6.

${ }^{5} \mathrm{We}$ do not distinguish between marriage and cohabitation.

${ }^{6}$ A large breakdown of the IT system behind the National Tests implied that $7 \%$ did not take the test as planned (see Rambøll, 2013). In 2012 not all of the pupils enrolled in public schools in 2010 continued in public schools: $95.86 \%$ of the students who were in public schools $2^{\text {nd }}, 4^{\text {th }}$, or $6^{\text {th }}$ grade, were enrolled in public schools again in 2012, while 3.84 $\%$ of the students had moved to a private school where they are not part of the systematic National Tests, and the last $0.30 \%$ had moved to special schools or boarding schools.

${ }^{7}$ In order to construct one test score, comparable to the existing literature, we create a standardized average of test scores across the three profile areas. To account for possible differences in the scales across profile areas, we first standardize the scores for each profile area for each grade-year combination before we average the scores. Finally we standardize the average of the standardized profile areas for each grade-year combination in order to ensure that the average test score has a standard deviation of one and a mean of zero.
} 
cohorts have more disruptive children before the new children enter the school-cohort. In total the school-cohorts that receive disruptive children, no matter how it is measured, have on average a less favorable socio-economic background. Hence it is crucial for our analysis to include this rich conditioning set.

Slightly more than $90 \%$ of the school-cohorts receive or lose a pupil between the two tests, causing shifts in peer composition over the two-year period. Three out of four school-cohorts receive a new peer with divorced parents. Also three out of four cohorts receive or lose a new peer with parents who have a criminal background. While $19 \%$ of the cohorts receive a new pupil with a psychiatric diagnosis, only $14 \%$ lose a pupil with such a diagnosis. This difference between the inflow and the outflow reflects the increasing tendency of inclusion of mentally disabled pupils in mainstream schools. For details, see Table A4.

In total $21 \%$ of the children in our sample have divorced parents and around $27 \%$ of the children in our sample have parents where at least one - typically the father - has committed a crime before the child starts school. These families tend to move more than others and therefore many schoolcohorts either receive or lose a child with these characteristics. Fewer than $5 \%$ of the mothers have committed a crime before the child starts school compared to $24 \%$ of the fathers. The most common types of crime committed by the fathers are property crime (16\%), drugs and weapon related felonies $(10 \%)$ and violence $(6 \%)$. In total $11 \%$ of the fathers have at some point gone to prison, and about $2 \%$ of the fathers have been to prison due to a traffic violation.

\section{Estimation Strategy}

The panel nature of our dataset allows us to estimate peer effects in a value added framework. We estimate the effect of receiving a disruptive peer in the school-cohort on test scores, conditional on lagged test scores, lagged school-cohort characteristics and information on individual and family background. We measure potential disruptiveness through indicators of the family environment prior to school enrollment as described above. We are interested in how the presence of disruptive children in the school environment affects peers, but contemporaneous disruptiveness of one student might be affected by the behavior and performance of other children. It will therefore be difficult to disentangle who is influencing whom due to the simultaneous nature of peer effects. Our first two measures of disruptiveness: divorced parents and criminal parents are measured before the children enter school, and the last measure: children with a psychiatric diagnosis, is measured before they turn 9, and thus before the first test; it is thus very unlikely that they are affected by 
their new school mates. Many psychiatric diagnoses are not discovered until the child starts school. Almost $2 \%$ of children in mainstream classrooms were diagnosed with a mental disorder at 8 years, but only $43 \%$ of those were diagnosed before they started school. Also the composition of diagnoses differs for those diagnosed before they started school and those who were diagnosed before age 8 . Among the 8 year olds ADHD is the most common diagnosis, while among the 5 year olds the most prevalent diagnoses are neurodevelopmental disorders, autism, and eating disorders.

We estimate the following model for test score, $y$ :

$$
\begin{aligned}
y_{i c t}= & \alpha+\beta \cdot \text { Disrupt }_{c t}+\rho \cdot \text { Movement }_{c t}+\delta \cdot y_{i c, t-1}+\theta \cdot \text { Size }_{c, t-1}+\phi \cdot \text { Grade }_{c, t-1}+\tau \cdot \text { BaseYear }_{c} \\
& +\omega \cdot \text { BaseYear }_{c} \cdot \text { Grade }_{c, t-1}+\lambda \cdot \text { ShareDisrupt }_{c, t-1}+\pi \cdot x_{i c, 0}+\gamma \cdot \text { School }_{c, t-1}+\varepsilon_{i c t},
\end{aligned}
$$

where $i$ indicates the child, $c$ the class (school-cohort), and $t$ time. Disrupt is a $1 \times 2$ vector where the first entry takes the value one if a disruptive child has entered the school-cohort since $t-1$ and the other takes the value one if a disruptive child has left the school-cohort since $t-1$. Movement is a $1 \times 2$ vector that registers any movement into or out of the school-cohort. ${ }^{8}$ The parameter associated with receiving a disruptive child (Disrupt) is the parameter of interest and the counterfactual is receipt of a non-disruptive child. Size indicates the size of the school-cohort, ShareDisrupt is the share of disruptive children at the school-cohort at $t-1, x$ includes individual level background characteristics measured before the child starts school, ${ }^{9}$ and $S c h o o l$ is a vector of school indicator dummies. By including grade and base year fixed effects and interaction of those two, we are able to control for differences in means of the test scores in each base year by grade level cell. We allow the error term $\varepsilon$ to be clustered at the school level.

In the value added framework the movement of the pupils needs only be exogenous to the changes in test scores and not to the levels, as our conditioning set includes previous test scores. This is less restrictive than a model that regresses gains in test scores on observables given that the inclusion of previous test scores captures the unobservables in the school and home environment that influences

\footnotetext{
${ }^{8}$ Gibbons and Telhaj (2011) document that this general movement has a negative effect on the students in the receiving classrooms. They find that an increase in annual entry rates from 0 to $10 \%$ would set back students by $5 \%$ of a standard deviation between the ages 7 and 11. Thus it is important to separate these effects from our estimate of how disruptive peers affect their classmates.

${ }^{9}$ In contrast to the moving children, psychiatric diagnoses of the receiving children are also measured before they start school
} 
test scores. ${ }^{10}$ The rest of the conditioning set is assumed to account for other differences there might be.

The two components of the vector Movement capture any general effects of school-cohort disruption, or the effects of increasing the school-cohort size. Larger schools covering larger districts will typically experience more movement; we thus include Size which controls for the effects of the school-cohort size that otherwise would have an indirect effect on our results. Test scores are standardized on the full sample for each year and grade level to have zero mean and unit variance, we include grade fixed effects to control for any differences in the means of the test scores that are due to sample selection. By including ShareDisrupt we allow for the possibility that school-cohorts with a high share of disruptive children might be more likely to receive an extra pupil. Finally school fixed effects and individual characteristics allow for differences in the probability of receiving a disruptive child across socio-economic status and across schools. ${ }^{11}$

We use indicator variables to measure movement of children into and out of the peer group rather than changes in the fractions. This strategy allows for asymmetries and nonlinearities of the effects in a simple fashion. The distributions of movements into the school-cohort are shown in Figure 1. They suggest that a substantial part of the variation in the influx comes from the extensive margin: whether one potentially disruptive child enters the class or not (0/1). For diagnosed children, only $20 \%$ of the observations involve more than one child moving, while for children of divorced parents and children with criminal parents, $70 \%$ of the observations involve more than one child moving. In the former case a linearity assumption would not be overly restrictive because almost all variation comes from the margin zero to one, whereas in the latter case a linearity assumption would be more restrictive because it requires that the impact of each additional potentially disruptive child is the same.

\footnotetext{
${ }^{10}$ Todd and Wolpin (2003) note that a model that regress the gains in test scores on observables without the lagged test score is a more restrictive version of the value added model as it corresponds to a model where $\delta=1$. As a robustness check we estimate this more restrictive model.

${ }^{11}$ While we are convinced that the characteristics of the students moving into the school cohorts cannot have affected the new peers before they move in to the new school, we expect that pupils who move out might both affect the child before the move but also after they have left, as they might still influence each other out of school. Thus the mechanisms of how peers are affected by losing a classmate are not as clear cut, and therefore we have our main focus on students moving into the cohort.
} 
FIGURE 1

DISTRIBUTION OF THE INFLUX OF CHILDREN
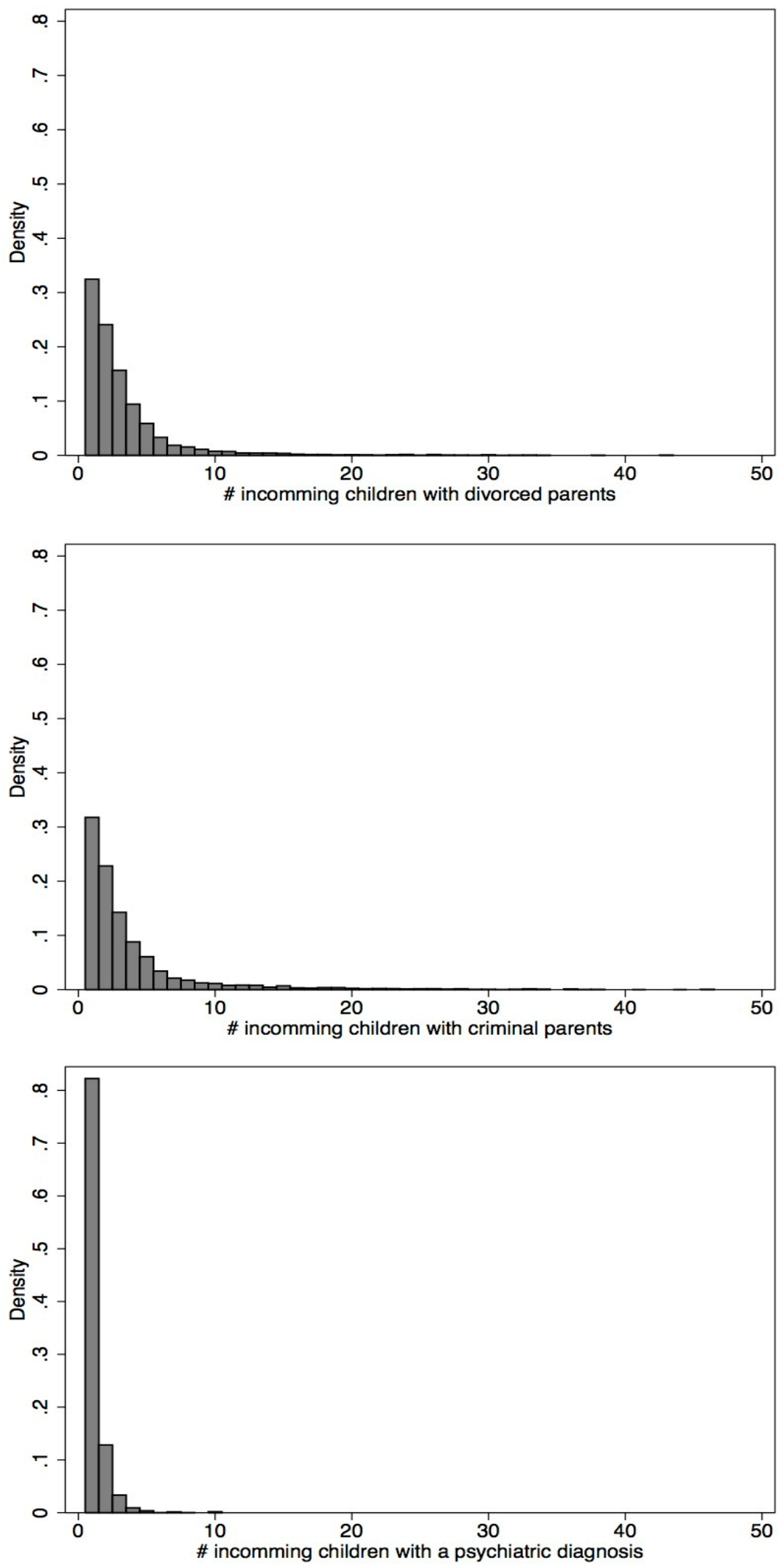
As discussed above some children may receive aids during the tests, and this will possibly affect the test scores, but we are unfortunately not able to observe this, and hence control for it. But in the same way that test scores in 2012 (2013) are a function of the test environment, the scores in 2010 (2011) are influenced by the test environment in 2010 (2011). Thus by conditioning on lagged test scores - and in essence looking at gains in test scores instead - we will resolve this problem as long as differences over time in aids offered to the child is orthogonal to receiving a new peer. ${ }^{12}$ In this analysis we can only use information from children who have test scores from both 2010 (2011) and 2012 (2013). We believe that children who are exempted from the tests are typically children who would perform poorly if they were to take the test. We might therefore not be able to capture how the worst performing children will be affected by a new disruptive peer.

We estimate a linear probability model to investigate how much of the variation in increase of disruptive children can be explained by our conditioning set. This model will give us an idea of how well the increases can be predicted by characteristics of the school-cohort or to what extent it is an exogenous shock to the peer composition.

\footnotetext{
${ }^{12} \mathrm{We}$ do not believe that the teachers' possibility to assist the children is a large problem, but we cannot completely rule out that the teachers in the classes that receive a disruptive child try to compensate for the disruption by giving more aid to the rest of the class during the test. This would mask some of the negative effect that the disruptive children might have on the classmates, thus potentially bias our results towards zero. Alternatively the teacher could be forced to spend all the time helping the potentially disruptive child and thus have less time to assist the rest of the class; this would bias our results in the other direction.
} 
TABLE 1

LINEAR REGRESSION,

LIKELIHOOD OF RECEIVING A DISRUPTIVE PEER

\begin{tabular}{|c|c|c|c|c|}
\hline Variable & $\begin{array}{c}\text { Increase of childrer } \\
\text { with divorced } \\
\text { parents } \\
\end{array}$ & $\begin{array}{l}\text { crease of childr } \\
\text { with criminal } \\
\text { parents }\end{array}$ & $\begin{array}{c}\text { Increase of children } \\
\text { with a psychiatric } \\
\text { diagnosis }\end{array}$ & Mean \\
\hline \multicolumn{5}{|l|}{ Child: } \\
\hline Test score, Reading (base year) & $\begin{array}{l}-0.0006 \\
(0.0014)\end{array}$ & $\begin{array}{c}0.0013 \\
(0.0013)\end{array}$ & $\begin{array}{c}0.0017 \\
(0.0012)\end{array}$ & 0.0301 \\
\hline Divorced parents $(0 / 1)$ & $\begin{array}{l}-0.0032 \\
(0.0020)\end{array}$ & $\begin{array}{c}0.0021 \\
(0.0019)\end{array}$ & $\begin{array}{c}0.0024 \\
(0.0019)\end{array}$ & 0.2049 \\
\hline Parents who committed non-traffic crime $(0 / 1)$ & $\begin{array}{c}0.0023 \\
(0.0020)\end{array}$ & $\begin{array}{c}-0.0049 * * \\
(0.0021)\end{array}$ & $\begin{array}{c}0.0012 \\
(0.0019)\end{array}$ & 0.2696 \\
\hline Psychiatric diagnosis at age $5(0 / 1)$ & $\begin{array}{c}0.0156^{* *} \\
(0.0078)\end{array}$ & $\begin{array}{l}-0.0001 \\
(0.0082)\end{array}$ & $\begin{array}{l}-0.0012 \\
(0.0078)\end{array}$ & 0.008 \\
\hline Parents committed violent crime or have been to prison $(0 / 1)$ & $\begin{array}{l}-0.0023 \\
(0.0028)\end{array}$ & $\begin{array}{c}0.0031 \\
(0.0028)\end{array}$ & $\begin{array}{c}-0.0053 * * \\
(0.0026)\end{array}$ & 0.1213 \\
\hline Immigrant $(0 / 1)$ & $\begin{array}{c}0.0055 \\
(0.0036)\end{array}$ & $\begin{array}{c}0.0071 * * \\
(0.0034)\end{array}$ & $\begin{array}{c}0.0068 * * \\
(0.0031)\end{array}$ & 0.0745 \\
\hline Birth weight less than 1500 grams $(0 / 1)$ & $\begin{array}{c}-0.0051 \\
(0.0060)\end{array}$ & $\begin{array}{c}0.0049 \\
(0.0061)\end{array}$ & $\begin{array}{l}-0.0009 \\
(0.0058)\end{array}$ & 0.0295 \\
\hline Birth weight $1500-2500$ grams $(01)$ & $\begin{array}{l}-0.0013 \\
(0.0041)\end{array}$ & $\begin{array}{l}0.0072^{*} \\
(0.0041)\end{array}$ & $\begin{array}{c}0.0017 \\
(0.0039)\end{array}$ & 0.0374 \\
\hline Male $(0 / 1)$ & $\begin{array}{l}-0.0027^{*} \\
(0.0016)\end{array}$ & $\begin{array}{l}-0.0001 \\
(0.0014)\end{array}$ & $\begin{array}{l}-0.0008 \\
(0.0014)\end{array}$ & 0.5 \\
\hline APGAR5 not $10(0 / 1)$ & $\begin{array}{c}0.0003 \\
(0.0031)\end{array}$ & $\begin{array}{c}0.0010 \\
(0.0031)\end{array}$ & $\begin{array}{l}-0.0015 \\
(0.0029)\end{array}$ & 0.2631 \\
\hline Size of cohort at school & $\begin{array}{c}0.0004 \\
(0.0005)\end{array}$ & $\begin{array}{c}0.0003 \\
(0.0005)\end{array}$ & $\begin{array}{c}-0.0002 \\
(0.0006)\end{array}$ & 52.034 \\
\hline \multicolumn{5}{|l|}{ Mother: } \\
\hline Number of older siblings & $\begin{array}{c}0.0001 \\
(0.0010)\end{array}$ & $\begin{array}{c}0.0011 \\
(0.0010)\end{array}$ & $\begin{array}{l}-0.0009 \\
(0.0009)\end{array}$ & 0.7071 \\
\hline Age (when child is 5 years old) & $\begin{array}{c}0.0000 \\
(0.0002)\end{array}$ & $\begin{array}{l}-0.0003 \\
(0.0002)\end{array}$ & $\begin{array}{c}-0.0005 * * \\
(0.0002)\end{array}$ & 29.628 \\
\hline Degree of unemployment & $\begin{array}{c}0.0019 \\
(0.0049)\end{array}$ & $\begin{array}{l}-0.0024 \\
(0.0047)\end{array}$ & $\begin{array}{l}0.0078^{*} \\
(0.0047)\end{array}$ & 0.0549 \\
\hline Gross income (2000 prices, in 100,000 DKK) & $\begin{array}{c}0.0003 \\
(0.0009)\end{array}$ & $\begin{array}{c}0.0001 \\
(0.0008)\end{array}$ & $\begin{array}{c}0.0012 \\
(0.0009)\end{array}$ & 1.8602 \\
\hline High school (0/1) & $\begin{array}{l}-0.0008 \\
(0.0033)\end{array}$ & $\begin{array}{l}-0.0039 \\
(0.0032)\end{array}$ & $\begin{array}{l}-0.0013 \\
(0.0032)\end{array}$ & 0.0708 \\
\hline Vocational $(0 / 1)$ & $\begin{array}{c}0.0019 \\
(0.0025)\end{array}$ & $\begin{array}{l}-0.0006 \\
(0.0024)\end{array}$ & $\begin{array}{c}0.0001 \\
(0.0023)\end{array}$ & 0.307 \\
\hline 2-year college $(0 / 1)$ & $\begin{array}{c}0.0015 \\
(0.0043)\end{array}$ & $\begin{array}{l}-0.0037 \\
(0.0042)\end{array}$ & $\begin{array}{l}-0.0017 \\
(0.0040)\end{array}$ & 0.0366 \\
\hline 4-year college $(0 / 1)$ & $\begin{array}{c}0.0026 \\
(0.0031)\end{array}$ & $\begin{array}{l}-0.0026 \\
(0.0031)\end{array}$ & $\begin{array}{l}-0.0008 \\
(0.0030)\end{array}$ & 0.1794 \\
\hline MSc or PhD degree $(0 / 1)$ & $\begin{array}{c}0.0056 \\
(0.0044)\end{array}$ & $\begin{array}{l}-0.0019 \\
(0.0042)\end{array}$ & $\begin{array}{l}-0.0029 \\
(0.0046)\end{array}$ & 0.0641 \\
\hline
\end{tabular}


TABLE 1 - CONTINUED

LINEAR REGRESSION,

LIKELIHOOD OF RECEIVING A DISRUPTIVE PEER

\begin{tabular}{|c|c|c|c|c|}
\hline \multicolumn{5}{|l|}{ Father: } \\
\hline Age (when child is 5 years old) & $\begin{array}{c}-0.0004 * * \\
(0.0002)\end{array}$ & $\begin{array}{l}-0.0000 \\
(0.0002)\end{array}$ & $\begin{array}{c}0.0004 * * * \\
(0.0002)\end{array}$ & 31.385 \\
\hline Degree of unemployment & $\begin{array}{c}-0.0167 * * * \\
(0.0064)\end{array}$ & $\begin{array}{c}0.0077 \\
(0.0057)\end{array}$ & $\begin{array}{c}0.0038 \\
(0.0057)\end{array}$ & 0.0315 \\
\hline Gross income (2000 prices, in $100,000 \mathrm{DKK}$ ) & $\begin{array}{c}-0.0008 * * \\
(0.0003)\end{array}$ & $\begin{array}{l}-0.0002 \\
(0.0005)\end{array}$ & $\begin{array}{l}-0.0001 \\
(0.0003)\end{array}$ & 2.8203 \\
\hline High school (0/1) & $\begin{array}{c}-0.0008 \\
(0.0039)\end{array}$ & $\begin{array}{l}-0.0013 \\
(0.0037)\end{array}$ & $\begin{array}{c}0.0025 \\
(0.0038)\end{array}$ & 0.0494 \\
\hline Vocational $(0 / 1)$ & $\begin{array}{c}0.0051 * * \\
(0.0023)\end{array}$ & $\begin{array}{c}0.0032 \\
(0.0022)\end{array}$ & $\begin{array}{l}-0.0022 \\
(0.0021)\end{array}$ & 0.3518 \\
\hline 2-year college $(0 / 1)$ & $\begin{array}{r}0.0080^{* *} \\
(0.0037)\end{array}$ & $\begin{array}{l}0.0068^{*} \\
(0.0036)\end{array}$ & $\begin{array}{c}0.0006 \\
(0.0033)\end{array}$ & 0.0565 \\
\hline 4-year college $(0 / 1)$ & $\begin{array}{l}-0.0014 \\
(0.0033)\end{array}$ & $\begin{array}{c}0.0019 \\
(0.0031)\end{array}$ & $\begin{array}{c}-0.0065^{* *} \\
(0.0033)\end{array}$ & 0.1049 \\
\hline MSc or PhD degree $(0 / 1)$ & $\begin{array}{l}-0.0048 \\
(0.0044)\end{array}$ & $\begin{array}{l}-0.0087 * \\
(0.0044)\end{array}$ & $\begin{array}{c}-0.0088^{* *} \\
(0.0041)\end{array}$ & 0.0851 \\
\hline Started in 4th grade & $\begin{array}{c}0.0148 \\
(0.0178)\end{array}$ & $\begin{array}{c}0.0591 * * * \\
(0.0178)\end{array}$ & $\begin{array}{l}-0.0250 \\
(0.0157)\end{array}$ & \\
\hline Started in 6th grade & $\begin{array}{c}0.0791 * * * \\
(0.0178)\end{array}$ & $\begin{array}{c}0.1049 * * * \\
(0.0191)\end{array}$ & $\begin{array}{c}0.0040 \\
(0.0183)\end{array}$ & \\
\hline BaseYear 2011 & $\begin{array}{c}0.0039 \\
(0.0186)\end{array}$ & $\begin{array}{c}0.0273 \\
(0.0192)\end{array}$ & $\begin{array}{c}0.0116 \\
(0.0176)\end{array}$ & \\
\hline Started in 4th grade X Base Year 2012 & $\begin{array}{c}0.0318 \\
(0.0248)\end{array}$ & $\begin{array}{l}-0.0139 \\
(0.0246)\end{array}$ & $\begin{array}{c}0.0567 * * \\
(0.0231)\end{array}$ & \\
\hline Started in 6th grade X Base Year 2012 & $\begin{array}{c}0.0110 \\
(0.0242)\end{array}$ & $\begin{array}{c}0.0065 \\
(0.0240)\end{array}$ & $\begin{array}{c}0.0903 * * * \\
(0.0255)\end{array}$ & \\
\hline Observations & 238,795 & 237,815 & 246,022 & 246,590 \\
\hline $\begin{array}{l}\text { F-test variables above without grade and Base Year ( } \mathrm{p} \text {-value) } \\
\mathrm{R}^{2}\end{array}$ & $\begin{array}{l}0.0124 \\
0.3300 \\
\end{array}$ & $\begin{array}{l}0.1239 \\
0.3545 \\
\end{array}$ & $\begin{array}{l}0.0236 \\
0.2964 \\
\end{array}$ & \\
\hline $\begin{array}{l}\text { Controls } \\
\text { School FE }\end{array}$ & YES & YES & YES & \\
\hline
\end{tabular}

Table 1 reports the results. We regress each of the disruption-increase dummies on our explanatory variables; the first column shows the estimates for increase of children with divorced parents, the second shows the estimates for increase of children with parents with a criminal background, and the third shows the estimates for increase of children with an early psychiatric diagnosis. ${ }^{13}$ Importantly, while some coefficient estimates in the regressions of movements on background characteristics are significant, the size of the estimates is always small relative to mean values and the signs do not indicate any particular type of selection. We are not surprised about the occasional

\footnotetext{
${ }^{13}$ Another way of performing this type of test is to perform a regression of each of the individual characteristics on the disruption-increase dummies. The conclusions are qualitatively the same and results are available upon request.
} 
significance since our models include more than 200,000 observations. In fact, the P-values on the F-tests of joint significance of individual level background characteristics indicate that increases of children of parents with a criminal background are unrelated to observable characteristics. Formally, we cannot reject the null hypothesis that coefficient estimates are zero (P-value 0.124). In contrast, there may be some correlation in the cases with children of divorced parents (P-value 0.012) and with regards to the influx of children with a psychiatric diagnosis $(0.024)$. We acknowledge this and control for the rich set of observable characteristics in our analysis. Since our main analysis relies on the assumption that the influx of disruptive children should be unrelated to changes in test scores given our conditioning set, it is comforting to see that our regressions show that increases of disruptive children is unrelated to the levels of test scores in the base year.

\section{Disruptive children}

The primary channel through which children with divorced or criminal parents or an early psychiatric diagnosis may affect their peers is thought to be through behavior, although other mechanisms may also be at work. The question is whether the indicators for potentially disruptive behavior actually capture disruptive behavior. For this reason, this section investigates behavior of potentially disruptive children. This analysis relies on auxiliary survey data on a subsample of sixth graders who completed the National Test in 2013; see Andersen, Beuchert and Nielsen (2014). Importantly, these survey data include information about self-reported answers to the Strengths and Difficulties Questionnaire (SDQ); see Goodman (1997). ${ }^{14}$ The SDQ covers five subscales: 1) emotional symptoms, 2) conduct problems, 3) hyperactivity/inattention, 4) peer relationship problems, and finally 5) pro-social behavior. 1) through 4) added together generates a total difficulties score. A high total difficulties score corresponds to a high level of difficulties. The fifth scale, in contrast, is a measure of strengths; here a high score is equivalent to more pro-social behavior. The scores of the five SDQ scales lies between 0 and 10 and the total difficulties score lies between 0 and 40 .

Table 2 shows the (unconditional) relationship between our measures of disruptiveness and the total difficulties score. Columns (1), (3), and (5) present simple regressions of SDQ on our measures of disruptiveness, while columns (2), (4), and (6) also allow for gender interactions. Columns (7)-(8) combine all variables in one model. Children of divorced and criminal parents exhibit significantly worse behavior than other children. Interestingly, we see that the correlation between SDQ and

\footnotetext{
${ }^{14}$ For complete information on the SDQ visit www.sdqinfo.org
} 
parental crime is higher for girls than for boys. Children with an early psychiatric diagnosis do, on average, score differently than other children. Note though that we only have information about children in mainstream classrooms, but the children moving into the classroom in our main analysis are not restricted to come from a mainstream classroom. Children who are more severely affected by their psychiatric disorder will most likely be placed in either a special needs class or in a special school. Thus, Table 2 shows a clear relationship between misbehavior and the indicators for potential disruptiveness. ${ }^{15}$

TABLE 2

LINEAR REGRESSION, TOTAL DIFFICULTIES SCORE ON MEASURES OF DISRUPTIVENESS

\begin{tabular}{|c|c|c|c|c|c|c|c|c|}
\hline Meassure of disruptiveness: & $(1)$ & $(2)$ & (3) & (4) & $(5)$ & $(6)$ & (7) & $(8)$ \\
\hline Divorced parents & $\begin{array}{c}1.635^{* * *} * \\
(0.184)\end{array}$ & $\begin{array}{c}1.618 * * * \\
(0.192)\end{array}$ & & & & & $\begin{array}{c}1.348^{* * *} \\
(0.185)\end{array}$ & $\begin{array}{c}1.286 * * * \\
(0.193)\end{array}$ \\
\hline Divorced parents * Boy & & $\begin{array}{c}0.036 \\
(0.217)\end{array}$ & & & & & & $\begin{array}{c}0.131 \\
(0.232)\end{array}$ \\
\hline Criminal parents & & & $\begin{array}{c}1.437 * * * \\
(0.136)\end{array}$ & $\begin{array}{c}1.679 * * * \\
(0.187)\end{array}$ & & & $\begin{array}{c}1.156^{* * * *} \\
(0.129)\end{array}$ & $\begin{array}{c}1.415 * * * \\
(0.187)\end{array}$ \\
\hline Criminal parents * Boy & & & & $\begin{array}{c}-0.489 * * \\
(0.238)\end{array}$ & & & & $\begin{array}{c}-0.522 * * \\
(0.253)\end{array}$ \\
\hline Psychiatric diagnosis & & & & & $\begin{array}{c}1.257 * * \\
(0.563)\end{array}$ & $\begin{array}{c}1.438 \\
(0.891)\end{array}$ & $\begin{array}{l}0.986^{*} \\
(0.558)\end{array}$ & $\begin{array}{c}1.263 \\
(0.824)\end{array}$ \\
\hline Psychiatric diagnosis * Boy & & & & & & $\begin{array}{l}-0.248 \\
(1.142)\end{array}$ & & $\begin{array}{l}-0.387 \\
(1.114)\end{array}$ \\
\hline Boy & & $\begin{array}{c}0.022 \\
(0.153)\end{array}$ & & $\begin{array}{c}0.150 \\
(0.116)\end{array}$ & & $\begin{array}{l}-0.015 \\
(0.144)\end{array}$ & & $\begin{array}{c}0.140 \\
(0.129)\end{array}$ \\
\hline Observations & 9,516 & 9,516 & 9,516 & 9,516 & 9,516 & 9,516 & 9,516 & 9,516 \\
\hline R-squared & 0.015 & 0.015 & 0.013 & 0.014 & 0.001 & 0.001 & 0.024 & 0.024 \\
\hline
\end{tabular}

Note: No other covariates than those listed are included in the regressions.

Standard errors are clustered at the school level and shown in parentheses. $* * * \mathrm{p}<0.01, * * \mathrm{p}<0.05, * \mathrm{p}<0.1$.

These results do not stand alone. For example, Bergström et al (2014) support what we find in terms of children with divorced parents. They find that the SDQ difficulties score among children from nuclear families is 7.34 as opposed to 8.96 among children whose parents enjoy joint custody and 9.57 among children in single care. Snyder et al (2001) show that children with incarcerated parents are at increased risk for abuse of drugs and alcohol, engaging in antisocial behavior, dropping out of school or experiencing a decline in school work as well as having high levels of truancy, aggression, and disruptive behaviors, compared to other children. As mentioned, the most

\footnotetext{
${ }^{15}$ The pattern is similar for each of the subscales. The only exception is that children with a psychiatric diagnosis score higher in the externalizing dimension only. The estimates for the individual subscales are available upon request.
} 
common psychiatric diagnosis established before the age of 9 is ADHD (18\%). Core symptoms associated with ADHD are well-known and include reduced attention span, hyperactivity, and impulsive behavior. In fact, SDQ has been shown to identify over $70 \%$ of individuals with conduct, hyperactivity, depressive and some anxiety disorders; Goodman et al. (2000).

\section{Effects on student outcomes}

This section first presents our main findings followed by a range of heterogeneity and robustness analyses.

\subsection{Main results}

Table 3 shows the results from our baseline estimations. For completeness, the table reports all coefficients associated with movement indicators. The first coefficient in each panel is the estimate of our parameter of interest that indicates the effect of an increase of potentially disruptive children. For completeness, we also show the coefficients associated with a decrease in potentially disruptive children and effects of movements in general. Columns (1)-(4) sequentially add control variables.

Panel A reports the estimations using children with divorced parents as the measure of potentially disruptive children. Column (1) shows coefficients from a regression only on the movement dummies and baseline test scores. Recall that the increase dummies indicate if there have been any (disruptive) children moving into the school and the decrease dummies indicate if there have been any (disruptive) children moving out of the school. Column (2) adds school fixed effects; column (3) adds school-cohort variables, and column (4) adds individual characteristics. Panel A shows that the point estimate associated with receiving a child with divorced parents is practically zero and insignificant after we control for school fixed effects and it remains stable when we include schoolcohort and individual characteristics. We interpret this as evidence that having peers with divorced parents does not seem to affect the pupil's performance gain.

Table 3, Panel B shows the estimates from our models where we consider children with parents who have committed a non-traffic crime before the child turns 6 as the group of possibly disruptive children. The coefficient associated with receiving a disruptive child shows that including a child with criminal parents into the school-cohort has a negative effect on the test score gain for the peers. The effect is again robust to the inclusion of more controls after the school fixed effect is controlled for and is significant at a $5 \%$ level in the full model. 
TABLE 3

RESULTS: READING

(1) (2)

(3)

(4)

Panel A

Children with divorced parents

Std. error

$\begin{array}{llll}-0.0160 * * & -0.0026 & -0.0029 & -0.0023\end{array}$

Decrease

$\begin{array}{llll}(0.0080) & (0.0082) & (0.0082) & (0.0081)\end{array}$

Std. error

$\begin{array}{llll}-0.0153 * & 0.0094 & 0.0095 & 0.0074\end{array}$

Any children

Increase

$\begin{array}{llll}(0.0078) & (0.0081) & (0.0082) & (0.0081)\end{array}$

Std. error

$\begin{array}{llll}0.0288 * * & 0.0085 & 0.0084 & 0.0098\end{array}$

Std. error

$\begin{array}{llll}(0.0141) & (0.0149) & (0.0149) & (0.0147)\end{array}$

Std. error

$\begin{array}{llll}0.0094 & 0.0078 & 0.0050 & 0.0072\end{array}$

$(0.0177)$

(0.0169)

$(0.0169) \quad(0.0166)$

Observations

$238,795 \quad 238,795 \quad 238,795 \quad 238,795$

R-squared

$\begin{array}{llll}0.5538 & 0.5744 & 0.5745 & 0.5832\end{array}$

\section{Panel B}

Children with criminal parents

\begin{tabular}{lcccc} 
Increase & $-0.0289 * * *$ & $-0.0178 * *$ & $-0.0189 * *$ & $-0.0168 * *$ \\
Std. error & $(0.0083)$ & $(0.0079)$ & $(0.0079)$ & $(0.0079)$ \\
Decrease & $-0.0163 * *$ & $0.0162 * *$ & $0.0168 * *$ & $0.0138 *$ \\
Std. error & $(0.0082)$ & $(0.0078)$ & $(0.0079)$ & $(0.0078)$ \\
Any children & & & & \\
Increase & $0.0371 * * *$ & 0.0199 & 0.0206 & 0.0206 \\
Std. error & $(0.0143)$ & $(0.0148)$ & $(0.0147)$ & $(0.0146)$ \\
Decrease & 0.0132 & 0.0048 & 0.0011 & 0.0032 \\
Std. error & $(0.0176)$ & $(0.0168)$ & $(0.0168)$ & $(0.0165)$ \\
& & & & \\
Observations & 237,815 & 237,815 & 237,815 & 237,815 \\
R-squared & 0.5534 & 0.5740 & 0.5741 & 0.5828 \\
\hline
\end{tabular}

Panel C

Children with a psychiatric diagnosis

\begin{tabular}{lcccc} 
Increase & $-0.0269 * * *-0.0260 * * *-0.0248 * * *-0.0233 * * *$ \\
Std. error & $(0.0079)$ & $(0.0080)$ & $(0.0080)$ & $(0.0079)$ \\
Decrease & -0.0117 & 0.0030 & 0.0016 & 0.0010 \\
Std. error & $(0.0085)$ & $(0.0084)$ & $(0.0085)$ & $(0.0085)$ \\
Any children & & & & \\
Increase & 0.0188 & 0.0124 & 0.0119 & 0.0138 \\
Std. error & $(0.0129)$ & $(0.0139)$ & $(0.0139)$ & $(0.0137)$ \\
Decrease & -0.0044 & 0.0099 & 0.0071 & 0.0092 \\
Std. error & $(0.0169)$ & $(0.0155)$ & $(0.0157)$ & $(0.0153)$ \\
& & & & \\
Observations & 246,022 & 246,022 & 246,022 & 246,022 \\
R-squared & 0.5528 & 0.5728 & 0.5728 & 0.5818 \\
\hline Controls & & & & \\
School FE & NO & YES & YES & YES \\
School-cohort characteristics & NO & NO & YES & YES \\
Individual characteristics & NO & NO & NO & YES \\
\hline \hline
\end{tabular}

Standard errors are clustered at the school level and shown in parentheses. $* * * \mathrm{p}<0.01, * * \mathrm{p}<0.05, * \mathrm{p}<0.1$. 
As the final measure of possibly disruptive children we consider children diagnosed with a mental disorder before age 9. Results for these estimations are shown in Panel C. The negative estimated effect of including a child with an early psychiatric diagnosis again remains stable when we include school-cohort characteristics and individual characteristics after we have controlled for school fixed effects. The effect of receiving a new peer with a psychiatric diagnosis is significant at a $1 \%$ level.

The size of the point estimates of $1.7 \%$ and $2.3 \%$ of a standard deviation reduction in the average test score in reading associated with influx of children with criminal parents and children with a psychiatric diagnosis is moderate. It compares to results found in the class-size literature which finds effects of including an extra student of about 2-5 percent of a standard deviation (see Angrist and Lavy (1999) and Fredriksson, Öckert and Oosterbeek (2013)) and is a bit smaller than the effects of including an English Language Learner found in Cho (2012). Remember that we do not use class level variation but instead use school-cohort level variation. If the disruptive behavior only affects students within the same classroom, then our estimated effect will be downward biased by the unaffected classrooms, as we estimate the average effect over all classrooms in the schoolcohort. We try to circumvent this issue in our robustness analysis below by restricting our sample to small schools with only one or two classrooms per cohort. The effect of between $1.7 \%$ and $2.3 \%$ of a standard deviation is the average effect of all the students in the school-cohort which on average is about 50 students, thus the total effect on all students in the cohort is substantial.

Acknowledging that these measures of possibly disruptive children are potentially positively correlated we estimate a joint model where we include indicators for all three measures of disruptive children. In fact the correlation coefficient between divorced parents and criminal parents are 0.21 , between psychiatric diagnosis and divorced parents it is 0.04 , and between criminal parents and psychiatric diagnosis it is 0.03 . The regressions in Table A5 show generally the same pattern as the regressions above. Both the effects of receiving a child with criminal parents and that of receiving a child with a psychiatric diagnosis are slightly lower than in the simple models and only significant at a $5 \%$ level.

To sum up, our estimations suggest that the inclusion of a disruptive pupil in a school-cohort can negatively influence the test score gain of the new peers. The estimated effects of receiving children whose parents are convicted of crime and children with a psychiatric diagnosis are robust to the inclusion of various controls. 


\subsection{Heterogeneity}

The effects found above suggest that children on average are negatively affected by sharing a classroom with a disruptive child. But it may very well be that the effect is larger for different age groups or across genders.

The results in Section 5 showed substantial gender variation in SDQ within our classes of disruptive children. It is thus natural to think that boys and girls with these characteristics will affect their peers differently. Recent work by Bertrand and Pan (2013) find similar gender differences in terms of externalizing behavior and find that the quality of the home environment is much more important to boys than girls: boys living with single mothers seem to have more disrupting behavior whereas girls do not.

In Table 4 we have re-estimated our main model distinguishing between the genders of the disruptive children. We estimate the model by including disruption and moment dummies by the gender of the moving children. Interestingly we now find that an influx of boys with divorced parents has a negative effect on peers' tests scores, whereas this is not the case for girls (note: that the estimates for influx of boys and girls with divorced parents are not statistically different from each other). It is consistent with the results found by Bertrand and Pan (2013) that boys are more affected by their parents not living together and therefore exert more adverse behavior toward their peers. The influx of children with criminal parents does not seem to differ by gender, though the point estimate for the influx of girls with criminal parents are higher than the one for boys, the effect of boys is only significant at a $10 \%$ level, whereas the estimate for girls is significant at a 5 $\%$ level. Note the two estimates do not significantly differ from each other. The same pattern emerges for boys and girls diagnosed with a psychiatric disorder, they affect their peers negatively, again we cannot reject that the two point estimates differ. This is not that surprising considering that the diagnosis criteria generally do not differ by gender. ${ }^{16}$

Our main analysis reports the average effect over all three cohorts of school children but it is not obvious that children in different age groups are affected in the same way. First, the nature of the disruptive behavior might change with age as the pupils mature. Second, we saw above that the frequency of movement change as the pupils gets older, but it might also be different children who

\footnotetext{
${ }^{16}$ We have estimated these models separately for females and males to test if the mechanism is such that girls influence girls and boys influence boys. We cannot reject the null hypothesis that disruptive children affect girls as much as boys. Results are available upon request.
} 
move at different times. Finally, the peers might not be equally affected by the disruptive peers in the early grades compared to the later grades. We therefore divide the sample into three groups by the grade they attended in the base year. We find that effects are generally bigger when the disruptive child moves into the classroom between $4^{\text {th }}$ and $6^{\text {th }}$ grade. The smaller sample sizes make the inference more imprecise, but the effect of receiving a child with a psychiatric diagnosis between $4^{\text {th }}$ and $6^{\text {th }}$ grade is significant on a $5 \%$ level. In general we cannot reject that the effects are equal across grade levels. ${ }^{17}$ Results are available upon request.

TABLE 4

RESULTS: READING, BY GENDER

\begin{tabular}{lccc}
\hline & $\begin{array}{c}\text { Divorced } \\
\text { Parent }\end{array}$ & $\begin{array}{c}\text { Criminal } \\
\text { Parents }\end{array}$ & $\begin{array}{c}\text { Psychiatric } \\
\text { Diagnosis }\end{array}$ \\
\hline & & & \\
Increase of girls & -0.0020 & $-0.0165^{* *}$ & $-0.0337^{* * *}$ \\
Std. Error & $(0.0075)$ & $(0.0073)$ & $(0.0104)$ \\
& & & \\
Increase of boys & $-0.0147^{* *}$ & $-0.0116^{*}$ & $-0.0220^{* *}$ \\
Std. Error & $(0.0068)$ & $(0.0069)$ & $(0.0097)$ \\
& & & \\
Observations & 238,795 & 237,815 & 246,022 \\
R-squared & 0.5833 & 0.5829 & 0.5819 \\
\hline Controls & & & \\
School FE & YES & YES & YES \\
School-cohort characteristics & YES & YES & YES \\
Individual characteristics & YES & YES & YES \\
\hline \hline
\end{tabular}

Note: The model estimated is a linear regression model controlling for previous test score, including dummies for decrease in the potentially disruptive boys and girls separately, and dummies for the general movements of boys and girls separately, for a detailed list of the remaining controls see Table A2.

Standard errors clustered at the school level and shown in parentheses $* * * \mathrm{p}<0.01, * * \mathrm{p}<0.05, * \mathrm{p}<0.1$.

\subsection{Robustness analyses}

Our rich set of controls above adjusts for differences in socio-economic backgrounds between schools, and the school fixed effects adjusts for differences between schools. If it is the case that

\footnotetext{
${ }^{17}$ This is tested by a Chow type test where the increase and decrease dummies are interacted with grade level dummies and we cannot reject that the parameters associated with the interaction terms is jointly zero.
} 
students select into schools based on unobservable differences between schools, then our school fixed effects would be pivotal, and the results would differ if the analysis were done on municipality fixed effects instead. Yet Table 5, column 2 shows that this is not the case. Our estimates are fairly stable and the conclusions above do not change.

It could, on the other hand, just be that school fixed effects are too crude to capture the unobserved differences between the children who receive a disruptive child and those who do not. We therefore proceed to estimate models that include family fixed effects. This is feasible since almost half of our sample consists of sibling pairs. The estimates from the model with sibling fixed effects are reported in Column 3. The reduction in sample size reduces the precision of the estimates slightly but the point estimates are stable. Thus we are confident that the differences between children in grade-cohorts who are exposed to an influx of disruptive children and those who are not, are captured by the rich set of controls and the school fixed effects we have included in the main analysis.

In the analysis above we have used school-cohorts of varying size; we have selected our sample size such that the size of the school-cohort is between 10 and 200. Danish school classes consist of a maximum of 28 students $^{18}$, thus the very large school-cohorts might have 7 or 8 different classes, whereas the smallest have only one class per cohort. It is highly plausible that peer effects mainly work within the classroom and the effect diminishes in the large cohorts where only one school class receives a potentially disruptive peer. We are therefore interested in whether the effect is more pronounced in small schools with a maximum of 50 students (corresponding to 2 school classes per cohort). This is of course a selected sample of our main sample as the small school tends to be placed in more rural areas. Column 4 of Table 5 reports the estimates for these smaller schools. The effects of receiving a peer with a psychiatric diagnosis are slightly higher than the effects found in the main analysis.

\footnotetext{
${ }^{18}$ The official maximum class size given by national law is 28 students, but effectively the maximum is only 24 , see Browning and Heinesen (2007).
} 
TABLE 5

RESULTS: READING, ROBUSTNESS CHECKS

\begin{tabular}{|c|c|c|c|c|c|c|c|c|}
\hline & (1) & (2) & (3) & (4) & $(5)$ & (6) & (7) & (8) \\
\hline & Main model & $\begin{array}{l}\text { Municipality } \\
\text { fixed effect }\end{array}$ & $\begin{array}{c}\text { Sibling fixed } \\
\text { effect }\end{array}$ & $\begin{array}{c}\text { Cohort size } \\
\text { under } 50\end{array}$ & $\begin{array}{l}\text { Stayed in } \\
\text { school- } \\
\text { cohort }\end{array}$ & $\begin{array}{c}\text { Movers who } \\
\text { moved } \\
\text { municipality }\end{array}$ & $\begin{array}{l}\text { Psych. diag. } \\
\text { measured at } \\
\text { age } 5\end{array}$ & $\begin{array}{c}\text { Incl. post- } \\
\text { test } \\
\text { movements }\end{array}$ \\
\hline \multicolumn{9}{|l|}{ Children with divorced parents } \\
\hline Increase & -0.0023 & -0.0082 & 0.0081 & 0.0016 & 0.0017 & -0.0051 & - & 0.0136 \\
\hline Std. error & $(0.0081)$ & $(0.0075)$ & $(0.0081)$ & $(0.0108)$ & $(0.0084)$ & $(0.0062)$ & - & $(0.0139)$ \\
\hline Observations & 238,795 & 238,795 & 108,241 & 123,890 & 221,727 & 243,623 & - & 106,175 \\
\hline \multicolumn{9}{|l|}{ Children with criminal parents } \\
\hline Increase & $-0.0168 * *$ & $-0.0160 * *$ & $-0.0159 * *$ & -0.0163 & -0.0114 & -0.0035 & - & -0.0192 \\
\hline Std. error & $(0.0079)$ & $(0.0076)$ & $(0.0081)$ & $(0.0112)$ & $(0.0081)$ & $(0.0061)$ & - & $(0.0129)$ \\
\hline Observations & 237,815 & 237,815 & 107,422 & 123,028 & 221,727 & 243,673 & - & 105,970 \\
\hline \multicolumn{9}{|c|}{ Children with a psychiatric diagnosis } \\
\hline Increase & $-0.0233 * * *$ & $-0.0198 * * *$ & $-0.0182 * *$ & $-0.0272 * *$ & -0.0135 & $-0.0448 * * *$ & $-0.0329 * * *$ & -0.0232 \\
\hline Std. error & $(0.0079)$ & $(0.0074)$ & $(0.0079)$ & $(0.0122)$ & $(0.0085)$ & $(0.0120)$ & $(0.0111)$ & $(0.0142)$ \\
\hline Observations & 246,022 & 246,022 & 110,825 & 128,340 & 221,727 & 246,378 & 246,367 & 108,761 \\
\hline \multicolumn{9}{|l|}{ Controls } \\
\hline School FE & YES & $\mathrm{NO}$ & $\mathrm{NO}$ & YES & YES & YES & YES & YES \\
\hline School-cohort characteristics & YES & YES & YES & YES & YES & YES & YES & YES \\
\hline Individual characteristics & YES & YES & YES & YES & YES & YES & YES & YES \\
\hline Municipality FE & $\mathrm{NO}$ & YES & $\mathrm{NO}$ & $\mathrm{NO}$ & $\mathrm{NO}$ & $\mathrm{NO}$ & $\mathrm{NO}$ & $\mathrm{NO}$ \\
\hline Sibling FE & $\mathrm{NO}$ & $\mathrm{NO}$ & YES & $\mathrm{NO}$ & $\mathrm{NO}$ & $\mathrm{NO}$ & $\mathrm{NO}$ & $\mathrm{NO}$ \\
\hline Post-test movements & $\mathrm{NO}$ & $\mathrm{NO}$ & $\mathrm{NO}$ & $\mathrm{NO}$ & $\mathrm{NO}$ & $\mathrm{NO}$ & $\mathrm{NO}$ & YES \\
\hline
\end{tabular}

Standard errors are clustered at the school level and shown in parentheses. $* * * \mathrm{p}<0.01, * * \mathrm{p}<0.05, * \mathrm{p}<0.1$. 
Another potential concern with our sample selection is that the children who stay at the same school are different from those who move around. Our main analysis included the non-disruptive children who have changed school between the two test scores, as long as they took the test in both years. Column 5 shows the estimates when we run the regression for the children who stayed in the same school. The estimates are a bit smaller in magnitude and insignificant, but point in the same direction. One could also be concerned that children are moved around within the same municipality in order to cope with their disabilities and potential disruptiveness and that the receiving school is chosen because it is better equipped to handle the disruptiveness. In Column 6 we report the estimates when we only consider disruptive children who have moved municipality. In some extreme cases parents may decide to move residence or split up as a consequence of the child's behavioral problems, in which case these effects should be stronger. If the parents strategically settle in school districts where they believe the children are less likely to affect the new peers, this would bias the results. However, our prior is that it is more likely that such moves are caused by factors other than child behavior; for example parental job opportunities. The effect of receiving children with parents who have a criminal history disappears when we only consider the children who moved municipality, whereas the effect of receiving children with a psychiatric diagnosis is much larger after imposing the additional restriction. This may suggest that children with criminal parents (a psychiatric diagnosis) who move to another municipality are less (more) disruptive compared to others.

Column 7 shows the results if we only consider the children who are diagnosed before they start school. It seems that they affect their peers to a larger degree than those who are diagnosed later. In many cases the symptoms of psychiatric disabilities only show after the children start school. Thus those who are diagnosed before might have more severe symptoms, and as a consequence be more disruptive.

Finally, column 8 includes indicators for future influx and outflow of potentially disruptive children. The idea is to see whether, conditioning on current peer composition, future composition has an independent effect on current achievement. This is, in a sense, a falsification test. If there is no selection based on trends then the future peers should have no effect on current achievement as long as one controls for current peers. ${ }^{19}$ This exercise does not change our main estimates, though it

\footnotetext{
${ }^{19}$ Note, though, that influx of potentially disruptive children today could potentially affect future movements out of the classroom (our estimations include test scores for children even if they leave the affected school cohort). In some sense therefore, conditioning on future movements corresponds to conditioning on an outcome.
} 
does affect significance (this is mainly because our sample size is reduced with around $50 \%$ because future data are only available for the oldest cohorts in our data set)

We have performed a series of additional robustness tests: a) we have run a regression with test score gains as an alternative outcome (equivalent to fixing $\delta=1$ in our estimation equation), b) we have estimated a model on school-cohorts where the change of students is less than $30 \%$ of the original school-cohort size, and c) we have changed the clustering level to municipalities. None of these modifications change the conclusions in our main analysis considerably and all are available upon request.

TABLE 6

RESULTS: MATH

\begin{tabular}{lccc}
\hline \hline Variables & $\begin{array}{c}\text { Divorced } \\
\text { parents }\end{array}$ & $\begin{array}{c}\text { Criminal } \\
\text { parents }\end{array}$ & $\begin{array}{c}\text { Psychiatric } \\
\text { diagnosis }\end{array}$ \\
\hline Increase & $-0.0540^{* *}$ & $-0.0502^{*}$ & -0.0107 \\
Std. error & $(0.0257)$ & $(0.0267)$ & $(0.0217)$ \\
Decrease & 0.0269 & -0.0106 & 0.0116 \\
Std. error & $(0.0262)$ & $(0.0267)$ & $(0.0207)$ \\
Any children & & & \\
Increase & $-0.1191^{*} *$ & $-0.1115^{* *}$ & $-0.1541^{* * *}$ \\
Std. error & $(0.0509)$ & $(0.0506)$ & $(0.0451)$ \\
Decrease & -0.0289 & -0.0070 & -0.0208 \\
Std. error & $(0.0594)$ & $(0.0613)$ & $(0.0578)$ \\
& & & \\
Observations & 38,272 & 38,199 & 39,552 \\
R-squared & 0.4170 & 0.4138 & 0.4181 \\
\hline Controls & & & \\
Municipality FE & YES & YES & YES \\
School-cohort characteristics & YES & YES & YES \\
Individual characteristics & YES & YES & YES \\
\hline \hline Standard errors are clustered at the school level and shown in parentheses \\
$* * *$ p $<0.01, * *$ p $<0.05, * p<0.1$ & & \\
& & &
\end{tabular}




\subsection{Math test scores}

Besides reading test scores we have math scores for one cohort. The children who attended $3^{\text {rd }}$ grade in spring 2010 and thus $6^{\text {th }}$ grade in spring 2013 have taken the National Test in math twice within our sample period. Below we repeat the same analysis for math test scores, as we did for reading above. Note that due to the timing of the National Tests, these test scores are three years apart, which means that there on average has been more movement in and out of the school-cohort. Furthermore, the children who have moved into the school-cohort have had longer time to influence the performance of their peers on average. As we only have one cohort at each school in our sample, employing school fixed effects is not feasible and we instead include municipality fixed effects. Recall that our results were robust to using municipality fixed effects instead of school fixed effects in the analysis of reading scores above.

The main results for math are shown in Table 6. First notice that receiving children with divorced parents reduces math test scores of the peers with $5 \%$ of a standard deviation. The effect of receiving a child with parents who have been convicted of crime is of the same magnitude but only significant at a $10 \%$ level. Children with a psychiatric diagnosis do not affect their peers' math scores to the same extent as the other two measures. The estimate for diagnosed children is more similar to what we found for reading scores but imprecisely estimated. The peer characteristics that lead to negatively spillovers on classmates thus seem to differ in reading and math.

\section{Concluding Remarks}

All over the world, children with various disadvantages and disabilities are being included in mainstream classrooms. However, only scarce evidence exists about the potential consequences of this policy trend for the other learners. This paper utilizes student mobility to investigate how student achievement is affected by potentially disruptive peers. We use information on marital status, criminal history of the parents and early psychiatric diagnoses of the children to identify possible disruptive peers. Nationwide, individual level panel data on tests in reading (and math) allow us to identify the effect of receiving additional disruptive peers conditional on prior test scores and a large set of information about individual characteristics and family background. To avoid simultaneity issues, we rely on early-life, pre-test measures of disruptiveness.

We find evidence that influx of a potentially disruptive child has negative consequences for the learning environment in the receiving school-cohort. It in fact lowers peers' academic achievement 
by about 1.7-2.3 percent of a standard deviation for reading. This is a robust but relatively moderate effect size. We perform a range of specification analyses, including a sibling fixed effects model. We believe that the similarity of the results provides a strong, if not completely conclusive, argument that we are identifying the effects of interest.

The effect seems to be strongest and most robust for peers in school-cohorts that receive a child with a psychiatric diagnosis. Children who receive a new peer with parents who have been convicted of a non-traffic crime seem also to be negatively affected in terms of their reading scores. Children with divorced parents have little effect on their peers, though this result masks considerable heterogeneity by gender: receiving boys with divorced parents significantly reduces tests scores, while receiving similarly affected girls have little bearing on peers' test scores. This suggests that the home environment is important especially for boys, and a poor home environment can spillover on peers and reduce their learning. 


\section{References}

Andersen, S., Beuchert, L. V., Nielsen, H.S., (2014), The Danish Co-teacher Experiment, Unpublished Manuscript, Aarhus University.

Angrist, J.D., and Lang, K., (2004), Does School Integration Generate Peer Effects? Evidence from Boston's Metco Program. American Economic Review, 94(5), 1613-1634.

Angrist, J.D., and Lavy, V., (1999), Using Maimonides' rule to estimate the effect of class size on scholastic achievement. Quarterly Journal of Economics 114(2), 533-575.

Bergström, E., Fransson, A. H., Köhler, L., and Wallby, T., (2014), Mental health in Swedish children living in joint physical custody and their parents' life satisfaction: A cross-sectional study. Scandinavian Journal of Psychology 55, 433-439.

Bertrand, M., and Pan, J., (2013), The Trouble with Boys: Social Influences and the Gender Gap in Disruptive Behavior. American Economic Journal: Applied Economics, 5(1), 32-64.

Beuchert, L. V. and Nandrup, A., (2014), The Danish National Tests - A Practical Guide, Economics WP \#2014-25, Aarhus University.

Billings, S. B., D. J. Deming and Rockoff, J., (2014), School Segregation, Educational Attainment, and Crime: Evidence from the End of Busing in Charlotte-Mecklenburg. Quarterly Journal of Economics, 129(1), 435-475.

Black, S.E., Devereux, P.J., and Salvanes, K.G., (2013), Under Pressure? The Effect of Peers on Outcomes of Young Adults. Journal of Labor Economics, 31(1), 119-153

Browning, M. and E. Heinesen (2007), Class Size, Teacher Hours and Educational Attainment. Scandinavian Journal of Economics 109 (2), 415-438.

Carrell, S.E., and Hoekstra, L.H., (2010), Externalities in the Classroom: How Children Exposed to Domestic Violence Affect Everyone's Kids. American Economic Journal: Applied Economics, 2(1), 211-228. 
Cho, R. M., (2012), Are There Peer Effects Associated with Having English Language Learner (ELL) Classmates? Evidence from the Early Childhood Longitudinal Study Kindergarten Cohort (ECLS-K). Economics of Education Review, 31(5), 629-643.

Diette, T.M. and Uwaifo Oyelere, R., (2014), Gender and Race Heterogeneity: The Impact of Students with Limited English on Native Students' Performance. American Economic Review, 104(5), 412-417.

Epple, D., and Romano, R.E., (2011), Peer effects in Education: A Survey of the Theory and Evidence. Handbook of Social Economics, 1B, 1053-1163.

European Agency for Development in Special Needs Education, 2013. Organisation of Provision to Support Inclusive Education - Literature Review, Odense, Denmark: European Agency for Development in Special Needs Education.

Figlio, D.N., (2007), Boys Named Sue: Disruptive Children and Their Peers. Education Finance and Policy, 2 (4), 376-394.

Fletcher, J.M., (2009), The Effects Of Inclusion On Classmates With Special Needs: The Case Of Serious Emotional Problems. Education Finance and Policy, 4(3), 278-299.

Fredriksson, P., Öckert, B., and Oosterbeek, H., (2013), Long-term Effects of Class Size. Quarterly Journal of Economics, 128(1), 249-285.

Gibbons, S., and Telhaj, S., (2011), Pupil mobility and school disruption. Journal of Public Economics, 95, 1156-1167.

Goodman, R. (1997), The Strengths and Difficulties Questionnaire: A Research Note. Journal of Child Psychology and Psychiatry, 38, 581-586.

Goodman, R., Ford, T., Simmons, H., Gatward, R., and Meltzer, H. (2000), Using the Strengths and Difficulties Questionnaire (SDQ) to screen for child psychiatric disorders in a community sample. British Journal of Psychiatry, 177, 534-539. 
Hanushek, E.A., Kain, J.F., Markman, J.M., and Rivkin S.G., (2003), Does Peer Ability Affect Student Achievement? Journal of Applied Econometrics, 18, 527-544.

Hanushek, E.A., Kain, J.F., and Rivkin S.G., (2002), Inferring Program Effects for Special Populations: Does Special Education Raise Achievement for Students with Disabilities? Review of Economics and Statistics, 84(4), 584-599.

Hoxby, C., and Weingarth, G., (2006), Taking Race out of the Equation: School Reassignment and the Structure of Peer Effects, Unpublished.

Imberman, S.A., Kugler, A.D., and Sacerdote B., (2012), Katrina's Children: Evidence on the Structure of Peer Effects from Hurricane Evacuees. American Economic Review, 102(5), 20482082.

Kristoffersen, J.H.G., (2013), Vulnerable Children and Peer Effects, in Empirical Essays on Economics of Education, Ch. 3 in PhD Thesis 2013-06, Department of Economics and Business, Aarhus University.

Lavy, V., Paserman, M. D., and Schlosser, A., (2012), Inside the Black Box of Ability Peer Effects: Evidence from Variation in the Proportion of Low Achievers in the Classroom. Economic Journal, 122(559), 208-237.

Lavy, V., and Schlosser, A. (2011). Mechanisms and Impacts of Gender Peer Effects at School. American Economic Journal: Applied Economics, 3(2), 1-33.

Lavy, V., Silva, O., and Weinhardt, F., (2012), The Good, the Bad, and the Average: Evidence on Ability Peer Effects in Schools. Journal of Labor Economics, 30(2), 367-414.

Rambøll (2013), Evaluering af de Nationale Test i Folkeskolen (In English: Evaluation of the National Tests in Elementary School), Rambøll Management Consulting.

Sacerdote, B., (2011), Peer Effects in Education: How Might They Work, How Big Are They and How Much Do We Know Thus Far? Handbook of the Economics of Education, 3, 249-277. 
Snyder, Z. K., Carlo, T. A., and Coats Mullins, M. M., (2001). Parenting from prison: An examination of a children's visitation program at a women's correctional facility. Marriage \& Family Review, 32, 33- 61.

Todd, E.P., and Wolpin, K.I., (2003), On the Specification and Estimation of the Production Function for Cognitive Achievement. Economic Journal, 113, F3-F33.

UNI-C (2012), Analyse af Nystartede Elever og Omgængere i Grundskolens Børnehaveklasse (In English: Analysis of Newly Enrolled and Retained Pupils in the Pre-School Year), UNI-C Styrelsen for IT og læring. 


\section{Appendix}

TABLE A1

\section{SAMPLE SELECTION}

\begin{tabular}{lcc}
\hline \hline & Reading & Math \\
\hline Children enrolled in public schools in 2nd, 4th, or 6th grade in base year & 324,136 & - \\
Children enrolled in public schools in 3rd grade in base year & - & 55,746 \\
Children completing National Test in base year & 297,068 & 48,968 \\
Children who also completed National Test two (reading) or three (math) years later & 273,499 & 44,910 \\
Children where at least some of their classmates continued on the same school in end year & 248,128 & 39,861 \\
Children in school-cohorts larger than 10 and smaller than 200 & 246,590 & 39,683 \\
\hline Excluding movers with divorced parents & 238,795 & 38,272 \\
Excluding movers with criminal parents & 237,815 & 38,199 \\
Excluding movers with psychiatric diagnosis & 246,022 & 39,552 \\
Excluding all movers classified as potentially disruptive & 233,924 & 37,545 \\
\hline \hline
\end{tabular}


TABLE A2

LIST OF INCLUDED COVARIATES

\section{Variable name \\ Basic controls \\ Test score (base year) \\ School-cohort characteris tics \\ Size of cohort at school}

Grade dummies

Base year dummy

Interaction of grade and base year dummies

Share of disruptive children

\section{Individual characteristics}

Child

Divorced parents $(0 / 1)$

Parents who committed non-traffic crime $(0 / 1)$

Psychiatric diagnosis at age $5(0 / 1)$

Parents committed violent crime or have been to pris on $(0 / 1)$ Immigrant $(0 / 1)$

Birth weight less than 1500 grams $(0 / 1)$

Birth weight 1500-2500 grams (01)

Male (0/1)

APGAR5 not $10(0 / 1)$

Mother

Number of older siblings

Age (when child is 5 years old)

Degree of unemployment

Gross income (2000 prices, in 100,000 DKK)

High school $(0 / 1)$

Vocational $(0 / 1)$

2-year college $(0 / 1)$

4-year college $(0 / 1)$

MSc or PhD degree (0/1)

Father

Age (when child is 5 years old) - mother

Degree of unemployment

Gross income (2000 prices, in 100,000 DKK)

High school $(0 / 1)$

Vocational $(0 / 1)$

2-year college $(0 / 1)$

4-year college $(0 / 1)$

MSc or PhD degree $(0 / 1)$

\section{Description}

Standardized test score in base year

Number of pupils on cohort at school in base year

Dummies indicating grade level

Dummy indicating if base year is 2010 or 2011

Interaction of grade level dummies and dummy indicating base year

Share of dis ruptive children at the school-cohort in base year

The parents are divorced at age 5

At least one parent who have committed a non-traffic crime by age 5

The child is diagnosed with a psychiatric diagnosis by age 5

At least one parent who have committed a violent crime or been to prison by age 5

The child is an immigrant

Birth weight classified as very low

Birth weight classified as low

Gender

Child had the maximum APGAR5 score

Number of children older than the pupil

Age when child was 5 years old

Fraction of time spend in unemployment the year the child turned 5 (in \%o)

Gross income in 2000 prices when child was 5

Highest completed education when child was 5 is high school

Highest completed education when child was 5 is vocational training

Highest completed education when child was 5 is 2-year college

Highest completed education when child was 5 is 4-year college

Highest completed education when child was 5 is $\mathrm{MSc}$ or $\mathrm{PhD}$ degree

Age when child was 5 years old

Fraction of time spend in unemployment the year the child turned 5 (in \%o)

Gross income in 2000 prices when child was 5

Highest completed education when child was 5 is high school

Highest completed education when child was 5 is vocational training

Highest completed education when child was 5 is 2-year college

Highest completed education when child was 5 is 4-year college

Highest completed education when child was 5 is MSc or PhD degree 
TABLE A3

MEANS OF OUTCOMES AND CONTROL VARIABLES, BY RECEIPT OF POTENTIALLY DISRUPTIVE CHILDREN

\begin{tabular}{|c|c|c|c|c|c|c|}
\hline \multirow[b]{2}{*}{ VARIABLES } & \multicolumn{2}{|c|}{ Divorced parents } & \multicolumn{2}{|c|}{ Criminal parents } & \multicolumn{2}{|c|}{ Psychiatric diagnosis } \\
\hline & Receivers & $\begin{array}{l}\text { Non- } \\
\text { receivers }\end{array}$ & Receivers & $\begin{array}{l}\text { Non- } \\
\text { receivers }\end{array}$ & Receivers & $\begin{array}{l}\text { Non- } \\
\text { receivers }\end{array}$ \\
\hline \multicolumn{7}{|l|}{ Child: } \\
\hline Test Score, Reading (final year) & 0.0401 & 0.0756 & 0.0390 & 0.0950 & 0.0073 & 0.0442 \\
\hline Test score, Reading (base year) & 0.0329 & 0.0658 & 0.0333 & 0.0793 & 0.0194 & $\mathbf{0 . 0 3 3 3}$ \\
\hline Divorced parents $(0 / 1)$ & 0.1820 & 0.1670 & 0.2030 & 0.1710 & 0.2170 & 0.2020 \\
\hline Parents who committed non-traffic crime $(0 / 1)$ & 0.2650 & 0.2500 & 0.2460 & 0.2300 & 0.2780 & 0.2670 \\
\hline Psy chiatric diagnosis $(0 / 1)$ & 0.0081 & 0.0069 & 0.0081 & 0.0073 & 0.0066 & 0.0072 \\
\hline Parents committed violent crime or been to prison $(0 / 1)$ & 0.1160 & 0.1100 & 0.1090 & 0.0988 & 0.1250 & 0.1200 \\
\hline Immigrant $(0 / 1)$ & 0.0804 & 0.0524 & 0.0817 & 0.0429 & 0.0802 & 0.0732 \\
\hline Birth weight less than 1500 grams $(0 / 1)$ & 0.0305 & 0.0259 & 0.0311 & 0.0243 & 0.0324 & 0.0289 \\
\hline Birth weight $1500-2500$ grams $(01)$ & 0.0372 & 0.0371 & 0.0375 & 0.0356 & 0.0380 & 0.0373 \\
\hline Male $(0 / 1)$ & 0.5000 & 0.5040 & 0.5010 & 0.5030 & 0.4970 & 0.5000 \\
\hline APGAR5 not $10(0 / 1)$ & 0.2560 & 0.2870 & 0.2590 & 0.2850 & 0.2570 & 0.2650 \\
\hline Size of cohort at school & 54.22 & 45.14 & 54.19 & 45.54 & 51.86 & 52.09 \\
\hline \multicolumn{7}{|l|}{ Mother } \\
\hline Number of older siblings & 0.7110 & 0.6900 & 0.7080 & 0.6810 & 0.7140 & 0.7060 \\
\hline Age at age 5 & 30.00 & 28.76 & 29.89 & 28.82 & 29.88 & 29.57 \\
\hline Degree of unemployment (in \%o) & 54.43 & 51.76 & 54.58 & 50.36 & 57.15 & 54.38 \\
\hline Gross income (2000 prices) & 188,631 & 183,445 & 187,806 & 185,365 & 187,529 & 185,757 \\
\hline High school (0/1) & 0.0721 & 0.0677 & 0.0718 & 0.0684 & 0.0711 & 0.0706 \\
\hline Vocational $(0 / 1)$ & 0.3090 & 0.3050 & 0.3080 & 0.3080 & 0.3110 & 0.3060 \\
\hline 2 -y ear college $(0 / 1)$ & 0.0371 & 0.0373 & 0.0369 & 0.0385 & 0.0353 & 0.0369 \\
\hline 4-y ear college $(0 / 1)$ & 0.1830 & 0.1790 & 0.1830 & 0.1840 & 0.1780 & 0.1800 \\
\hline MSc or $\mathrm{PhD}$ degree $(0 / 1)$ & 0.0666 & 0.0619 & 0.0665 & 0.0636 & 0.0618 & 0.0647 \\
\hline \multicolumn{7}{|l|}{ Father: } \\
\hline Age at age 5 & 31.78 & 30.51 & 31.65 & 30.52 & 31.76 & 31.30 \\
\hline Degree of unemploy ment (in \%o) & 31.53 & 26.90 & 32.01 & 23.23 & 33.73 & 30.98 \\
\hline Gross income (2000 prices) & 284,477 & 286,986 & 283,539 & 289,241 & 280,054 & 282,611 \\
\hline High school (0/1) & 0.0515 & 0.0435 & 0.0518 & 0.0431 & 0.0527 & 0.0487 \\
\hline Vocational $(0 / 1)$ & 0.3530 & 0.3520 & 0.3520 & 0.3550 & 0.3540 & 0.3510 \\
\hline 2-year college $(0 / 1)$ & 0.0580 & 0.0549 & 0.0575 & 0.0572 & 0.0566 & 0.0566 \\
\hline 4-y ear college $(0 / 1)$ & 0.1090 & 0.0998 & 0.1090 & 0.1030 & 0.1030 & 0.1050 \\
\hline MSc or $\mathrm{PhD}$ degree $(0 / 1)$ & 0.0880 & 0.0831 & 0.0883 & 0.0850 & 0.0810 & 0.0861 \\
\hline Observations & 185,414 & 53,381 & 185,021 & 52,794 & 44,544 & 201,478 \\
\hline
\end{tabular}

Note: Differences across groups which are significant at a $5 \%$ significance level are marked in bold. 
TABLE A4

MOBILITY AT SCHOOL-COHORT LEVEL BETWEEN 2010 AND 2012 OR 2011 AND 2013

\begin{tabular}{lccc}
\hline \hline Variable & Mean & Std. Dev. & Obs. \\
\hline Any increase in school-cohort & 0.922 & 0.269 & 6793 \\
Any decrease in school-cohort & 0.942 & 0.233 & 6793 \\
Increase of children with divorced parents & 0.741 & 0.438 & 6793 \\
Decrease of children with divorced parents & 0.740 & 0.439 & 6793 \\
Increase of children with criminal parents & 0.745 & 0.436 & 6793 \\
Decrease of children with criminal parents & 0.743 & 0.437 & 6793 \\
Increase of children with a psychiatric diagnosis & 0.189 & 0.391 & 6793 \\
Decrease of children with a psychiatric diagnosis & 0.141 & 0.348 & 6793 \\
\hline \hline
\end{tabular}

Note: The mean is the fraction of school-cohorts that have experienced an increase/decrease of the type of children listed in the left column. 
TABLE A5

RESULTS: READING,

INCLUDING ALL MEASURES OF POTENTIAL DISRUPTIVENESS

(1) $\quad(2) \quad$ (3)

Children with divorced parents

Increase

$\begin{array}{llll}-0.0051 & 0.0052 & 0.0047 & 0.0046\end{array}$

Std. error

$\begin{array}{llll}(0.0083) & (0.0085) & (0.0085) & (0.0084)\end{array}$

Decrease

$\begin{array}{llll}-0.0068 & 0.0063 & 0.0069 & 0.0053\end{array}$

Std. error

$(0.0080)$

$(0.0084) \quad(0.0085)$

(0.0084)

Children with criminal parents

$\begin{array}{lcccc}\text { Increase } & -0.0239 * * * & -0.0170 * * & -0.0183 * * & -0.0162 * * \\ \text { Std. error } & (0.0086) & (0.0082) & (0.0082) & (0.0081) \\ \text { Decrease } & -0.0124 & 0.0146 * & 0.0152 * & 0.0127 \\ \text { Std. error } & (0.0085) & (0.0081) & (0.0082) & (0.0081)\end{array}$

Children with a psychiatric diagnosis

Increase

$-0.0135 *-0.0185 * *-0.0182 * *-0.0183 * *$

Std. error

$\begin{array}{llll}(0.0081) & (0.0083) & (0.0083) & (0.0082)\end{array}$

Decrease

$\begin{array}{llll}-0.0051 & 0.0026 & 0.0016 & 0.0006\end{array}$

Std. error

$(0.0089)$

$(0.0087) \quad(0.0088)$

(0.0088)

Any children

Increase

$\begin{array}{llll}0.0402 * * * & 0.0179 & 0.0185 & 0.0186\end{array}$

Std. error

$\begin{array}{llll}(0.0150) & (0.0154) & (0.0153) & (0.0151)\end{array}$

Decrease

$\begin{array}{llll}0.0179 & 0.0032 & -0.0005 & 0.0022\end{array}$

Std. error

$\begin{array}{llll}(0.0181) & (0.0176) & (0.0175) & (0.0172)\end{array}$

\begin{tabular}{lcccc} 
Observations & 233,924 & 233,924 & 233,924 & 233,924 \\
R-squared & 0.5539 & 0.5748 & 0.5750 & 0.5836 \\
\hline Controls & & & & \\
School FE & NO & YES & YES & YES \\
School-cohort characteristics & NO & NO & YES & YES \\
Individual characteristics & NO & NO & NO & YES \\
\hline \hline
\end{tabular}

Standard errors are clustered at the school level and shown in parentheses.

$* * * \mathrm{p}<0.01, * * \mathrm{p}<0.05, * \mathrm{p}<0.1$. 